\title{
Az oxidatív stressz hozzájárul a krónikus vesebetegeket érintő vascularis kalcifikáció kialakulásához
}

\author{
Nyitrai Mónika ${ }^{1,3}$ - Balla György dr. ${ }^{2,3}$ - Balla József dr. ${ }^{1,3}$ \\ Debreceni Egyetem, Általános Orvostudományi Kar, ${ }^{1}$ Belgyógyászati Klinika, Nephrológiai Tanszék, \\ ${ }^{2}$ Gyermekgyógyászati Klinika, Neonatológiai Tanszék, Debrecen \\ ${ }^{3}$ MTA-DE Vascularis Biológia, Thrombosis-Haemostasis Kutatócsoport, Debrecen
}

\begin{abstract}
A rendszeres dialíziskezelésre szoruló vesebetegek körében a halálozási ok leggyakrabban valamilyen cardiovascularis megbetegedés. A cardiovascularis események egyik előidézője a vascularis kalcifikáció, amelynek kialakulási esélye a krónikus vesebetegek körében extrém magas. A kalcifikáció nemcsak az évtizedek óta dialízisterápiában részesülő idősebb korosztályban jelentkezik, hanem a fiatal korosztályt is érinti. Az érrendszerben megjelenő masszív, nagy kiterjedésű kalcifikáció aktív, jól szabályozott komplex folyamat eredményeként alakul ki. Előidézői között szerepel az oxidatív stressz, amely a beteg szervezetében a vese múködési zavara következtében nagymértékben fokozódik. A megemelkedett oxidatív terhelést tovább fokozzák a képződő oxidált LDL-formák, amelyek előidézői az endothelialis diszfunkciónak és az érben található simaizomsejtek csontszerű sejtté történő transzdifferenciációjának. Az oxidált hemoglobinból kiszabaduló szabad hem is képes az LDL oxidációjára és ezzel hozzájárul az atherosclerosis kialakulásához. A hemoxigenáz-1/ferritin rendszer indukciója mérsékli a szabad hem ezen káros hatásait. Orv. Hetil., $2015,156(47), 1926-1931$.
\end{abstract}

Kulcsszavak: vascularis kalcifikáció, krónikus veseelégtelenség, oxidatív stressz, oxidált LDL

\section{Oxidative stress: one of the major causes of vascular calcification in chronic kidney disease patients}

The leading cause of high mortality in dialyzed patients is cardiovascular disease. One of the main contributors of cardiovascular event is vascular calcification, which occurs even in very young patients. Multiple factors and complex mechanisms are involved in the formation of robust vascular calcification which affects a large vascular area observed in chronic kidney diseases. Patients on dialysis are exposed to enhanced oxidative stress as a result of increased prooxidant activity and reduced anti-oxidant systems. The oxidation of lipoprotein particles is implicated in the development of vascular damage representing oxidative threat, which leads to endothelial dysfunction. Moreover, in a prooxidant environment osteoblastic trans-differentiation of smooth muscle cells was shown to occur. Heme derived from oxidized hemoglobin might contribute to the formation of reactive lipid metabolites. This oxidative burden contributes to the development of atherosclerosis and vascular calcification. Heme oxygenase- 1 and ferritin may serve as intracellular defense mechanisms against such an insult.

Keywords: vascular calcification, renal insufficiency, oxidative stress, oxidized LDL

Nyitrai, M., Balla, Gy., Balla, J. [Oxidative stress: one of the major causes of vascular calcification in chronic kidney disease patients]. Orv. Hetil., 2015, 156(47), 1926-1931.

(Beérkezett: 2015. augusztus 18.; elfogadva: 2015. szeptember 13.) 


\section{Rövidítések}

$\mathrm{CKD}-\mathrm{MBD}=$ (chronic kidney disease - mineral and bone disorder) krónikus vesebetegség során megjelenő ásványi- és csontanyagcsere-zavar; FGF-23 = fibroblastnövekedési faktor 23; LDL = alacsony sürüségű lipoprotein; oxLDL-oxidált alacsony sürüségú lipoprotein; PMN = polimorfonukleáris leukocyták; PTH = parathormon; TBARS = tiobarbitursav-reaktív anyagok; USRDS $=$ United States Renal Data System

\section{Vascularis kalcifikáció vesebetegekben}

A vascularis kalcifikáció nem csak a mai kor emberére jellemző kórkép. A 2013-ban megjelent Horus-tanulmányban 4 különböző földrajzi területről származó 137 múmia CT-vizsgálata során 43\%-ban találtak atheroscleroticus plakkokat. A felvételeken látható nyaki verőér elmeszesedése a mai betegekben is hasonló képet mutat. A múmiákban észlelhető meszes képletek kialakulását kevésbé a táplálkozási szokásoknak, mintsem a krónikus fertőzéseknek és a gyulladásos folyamatoknak tulajdonítják [1].

A vascularis kalcifikáció és a vesebetegség kapcsolatára a XIX. században derült fény, és a XX. században a jelenség a nefrológusok tudományos érdeklődésének középpontjába került [2]. Ennek okai a már fiatalkorban megjelenő, nagyartériákat érintő és gyors progressziót mutató, kiterjedt kalcifikáció, továbbá a kalcifikációs urémiás arteriolopathiás esetek megnövekedett száma volt [3]. A vascularis kalcifikáció kialakulási esélye krónikus vesebetegek körében - különösen a dialízisterápiára szorulókban - extrém magas. Braun és mtsai dializált betegek körében végzett CT-vizsgálatok során több mint 80\%-ban mutattak ki vascularis kalcifikációt [4]. A csökkent GFR-rel (<60 ml/perc/1,73 $\left.\mathrm{m}^{2}\right)$ rendelkező betegek esetében a mineralizáció sokkal súlyosabb mértékú és kifejezetten gyorsabb progressziójú, mint az átlagpopulációban. Egy évtizedekkel ezelőtt induló és hosszan tartó dialízisterápia hatásait vizsgáló (1970-1994) tanulmányban, ahol a résztvevők átlagosan 16 éve álltak dialíziskezelés alatt, a nyomon követett betegek 92\%-ánál diagnosztizáltak vascularis kalcifikációt [5]. Az USRDS (United States Renal Data System) adatai szerint 2010ben az Egyesült Államokban a normálpopulációhoz képest a krónikus vesebetegek körében 59\%-kal magasabb a cardiovascularis eseményekkel összefüggő halálozási kockázat [6]. Ma Magyarországon minden tizedik ember érintett valamely vesebetegségben, évente közel 6500, krónikus veseelégtelenségben szenvedő beteg életben maradását biztosítja a múvesekezelés a Magyar Nephrologiai Társaság adatai szerint.

\section{A krónikus vesebetegség során megjelenő ásványi- és csontanyagcsere- zavar (CKD-MBD)}

A magas mortalitás egyik oka az ásványi- és csontanyagcsere-zavar. A foszfát- és kalciummetabolizmus zavarára visszavezethető cardiovascularis megbetegedés a krónikus vesebetegek többségében megjelenik [7]. Ezek megelőzése és/vagy kezelése napjainkban is kihívást jelent [8]. A krónikus vesebetegség során megjelenő ásványiés csontanyagcsere-zavar megnevezésére - amely magában foglalja a mineralizációs cardiovascularis rendellenességeket is - bevezették a betegség szisztémás jellegét leíró új fogalmat, a $\mathrm{CKD}-\mathrm{MBD}$ (chronic kidney disease - mineral and bone disorder) kifejezést [9].

Élettani vesemúködés esetén a szérumfoszfát koncentrációja 0,8-1,45 mmol/L. A foszfátszint emelkedése növeli a cardiovascularis események kockázatát, nemcsak a vesebetegek, hanem a normálpopuláció esetében is [10]. Egészséges egyéneknél, az élettani tartományon belül, a magasabb szint fokozott mineralizációs hajlamra utal. Krónikus vesebetegségben a vesefunkció hanyatlásával párhuzamosan (GFR $<60 \mathrm{~mL} /$ perc/1,73 $\left.\mathrm{m}^{2}\right)$ felborul a csont és ásványi anyagok homeosztázisa. A korai kimutatható változások a PTH (parathormon) és az FGF-23 (fibroblastnövekedési faktor 23) emelkedett mennyiségében, valamint a 25-hidroxi-D-vitamin és az 1,25-dihidroxi-D-vitamin csökkent szintjében mutatkoznak meg [9]. Mivel a szervezet az élettani szabályozásnak köszönhetően igyekszik a szérumfoszfát-koncentrációját egészséges tartományban tartani, az emelkedés később figyelhető meg (CKD, St. IV.). A csontanyagcsere-zavarok széles időskálán mozognak, egészen a lassú csontátépüléssel járó adinámiás csontbetegségtól a gyors csontátépülést eredményező osteitis fibrosa cysticáig. Az adinámiás csontbetegséget csökkent csontátépülés jellemzi, a kollagén szintézise és a mineralizáció a normálérték alatti. A kórkép megmutatkozik a dialíziskezelést kapó vesebetegek körében, de különösen gyakori a cukorbetegeknél. Előidézője a PTH túlzott alulszabályozottsága, a kalciumalapú foszfátkötők és az aktivált Dvitamin túlzott szedése. Az osteomalacia szintén lassú csontátépüléssel, a mineralizációs „lag time” emelkedésével jár, amelynek következménye nagy mineralizálatlan csonttömeg. A defektus megjelenését korábban fóként az alumíniumalapú foszfátkötőknek tulajdonították, azonban ezek elhagyásával előfordulása mára már csökkent. A megemelkedett PTH következtében kialakuló osteitis fibrosa cystica a csontállomány fokozott lebontásával és fokozott osteoclast-aktivitással járó kórkép.

Mind a gyors, mind a lassú csontátépülési defektusok mellett kialakulhat érrendszer-mineralizáció. A vascularis kalcifikáció fö típusait aszerint különböztetjük meg, hogy az érfal mely rétegében keletkeznek, valamint képeznek-e plakkokat. Az atheroscleroticus kalcifikáció az érfal intimarétegében jön létre, sejtes nekrózissal, gyulladással és lipidlerakódással jár. A Mönckeberg-arteriosclerosis esetén pedig a mineralizáció az érfal mediarétegében zajlik. A hosszú időn át fennálló magas szérumfoszfát-koncentráció növeli a kalcifilaxis előfordulását, amely a kiserek falának kalcifikációjával járó, életet veszélyeztető szövődmény [11]. 


\section{A vascularis kalcifikáció egyik előidézője: oxidatív stressz}

Sokáig a vascularis kalcifikációt az öregedéssel együtt járó passzív folyamatnak gondolták. Bár nem tagadhatjuk az életkorral való szoros kapcsolatot, ma már egy aktív, jól szabályozott, komplex folyamatként tekintünk rá, amelynek bizonyos részei a mai napig feltérképezetlenek maradtak. Az elmúlt két évtizedben a kalcifikációt elöidéző tényezőkről szerzett ismereteink nagymértékben gyarapodtak, amelyek között fontos helyen szerepel az oxidatív stressz.

A szervezetben jelentkező oxidatív stresszt az oxidáns anyagok túlsúlya és ezzel párhuzamosan az antioxidáns védelmi rendszer elégtelen múködése okozza. Prooxidánsok közé tartoznak a reaktívoxigén- és nitrogéngyökök (ROS, RNS), mint a szuperoxid anion, hidroxilgyökök és a hidrogén-peroxid. Normál körülmények között a sejt mitokondriumában zajló energiatermeló folyamatok során termelődik ROS, de ezenkívül számos enzimatikus folyamat termékeként is képződhet, például NADPH-oxidáz, xantinoxidáz, lipoxigenázok, ciklooxigenázok múködése során. A ROS fiziológiás koncentrációjának biztosításáért az antioxidáns védelmi rendszer enzimei (szuperoxid dizmutáz, kataláz, glutation-peroxidáz), vitaminok (E- és C-vitamin), átmeneti fémionok és különböző fehérjék (ferritin, transzferrin, albumin) felelősek $[12,13]$. Mindezen védőmechanizmusok ellenére a ROS túlzott mértékű felszaporodása és fehérjékkel, lipidekkel, nukleinsavakkal való reakciója sejtes és szöveti sérüléshez vezet.

Urémiás betegekben a vese múködési zavara oxidatív stresszel jár. Ez a plazma F2-izoprosztán, malondialdehid, különböző urémiás toxinok és oxidált fehérjék mennyiségének emelkedésében mutatkozik meg [14, 15]. A megemelkedett oxidatív behatásokról - közöttük az oxidált alacsony sûrúségú lipoprotein (oxLDL) formákról - ismert, hogy elősegítik a vascularis simaizomsejt osteoblastsejtté történő transzdifferenciációját. Ugyanakkor az is bebizonyosodott, hogy a csontban éppen ellenkezőleg, az oxidatív stressz gátlóhatással van az osteoblastok és csontvelői stromalis sejtek differenciációjára. Ez a kétféle sejttípusban megfigyelhető ellentétes válasz részben magyarázhatja a krónikus vesebetegségben, osteoporosisban egyszerre jelen lévő kalcifikációt (érben) és dekalcifikációt (csontban) [16].

Valójában a legtöbb krónikus vesebeteg előbb veszti életét valamilyen cardiovascularis esemény miatt, mint végstádiumú vesebetegségben [17]. A hemodialíziskezelés, annak ellenére, hogy a túlélést biztosítja, hosszú távon növeli a káros hatású oxidatív stresszt, ami minden bizonnyal hozzájárul a szöveti károsodások kialakulásához. A ROS-termeléssel járó rizikófaktorok a cukorbetegség, a dyslipidaemia, a magas vérnyomás, az előrehaladott kor, valamint az anaemia kezelésére adott intravénás vas. Ezenkívül a vesebetegség korai fázisában kimutatták a NADPH-oxidáz enzim aktivitásának és ex- pressziójának növekedését [18]. Végstádiumú vesebetegeknél pedig nagymértékú az apolipoprotein B-100 módosulása a hemoglobin LDL-hez való kötődése révén [19].

\section{Az oxidált LDL szerepe az atherosclerosis kialakulásában}

Az atherosclerosist előidéző tényezők közé tartozik a dyslipidaemia, amely a krónikus vesebetegek jellemző kórképe. Alacsony HDL- és magas trigliceridszint jellemzi [20]. Az emelkedett oxidatív stressz miatt kialakult endothelialis diszfunkció és a vascularis permeabilitás megváltozása lehetôvé teszi az LDL fokozott átjutását az endothelrétegen. Az LDL az érfal intimarétegében oxidálódik és gyulladásos folyamatokat indít el [21]. Az LDL oxidatív módosulása az atherosclerosis kialakulásának meghatározó eseménye. Kemotaktikus hatással van a keringő monocytákra, fokozza azok adhézióját és gátolja a laesióban már jelen lévő makrofágok motilitását. Az intima elhelyezkedésű monocytákból az oxidált LDL felvétele után úgynevezett habos sejtek (foam cell) jönnek létre, zsíros lerakódásokat képezve az érfalban. Ez a képződmény (fatty streak) az atherosclerosis folyamatának első morfológiai elváltozása. A folyamat előrehaladtával a tunica media rétegben található simaizomsejtek átvándorolnak a tunica intimába, proliferálnak, kollagénben és elasztinban gazdag extracelluláris mátrixot képeznek. Az így keletkezett fibrosus képlet elhatárolja a laesiót a keringő vértől. Gyulladásos folyamatok eredményeként azonban a plakk fala elvékonyodik és rupturál, a keletkező thrombus klinikai következményei a stroke és az infarktus [22].

Az LDL komponenseiból az oxidáció során sokféle biológiailag aktív termék jön létre, amelyek közül néhány erősen citotoxikus (7ß-hidroperoxi-koleszterin, 7-oxiszterolok). Az atheroscleroticus plakkokból származó lipidkivonatokban pedig megtalálhatók a különböző lipidperoxidációs termékek.

\section{Vas katalizálta oxidatív stressz (hemstressz)}

Vaseredetú reaktívoxigén-gyökök számos vascularis megbetegedésben szerepet játszanak, így az atherosclerosisban is. A keringő vörösvértestek $20 \mathrm{mmol} / \mathrm{L}$ koncentrációban tartalmaznak hemet, ami a szervezet legnagyobb vaskészletét képviseli. A hem a redoxaktív vas bőséges forrása, az intracelluláris hemfehérjékből kiszabadulva veszélyes oxidatív ágens.

Mivel a vascularis endothelium állandó kapcsolatban áll a keringő vörösvértestekkel, erősen ki van téve az exogén hem hatásainak. Az intravascularis vérzés vagy plakkruptura során a károsodott vörösvértestekből hemoglobin kerülhet a szöveti környezetbe. Az oxidációs folyamatok eredményeként a globinról a hem leválhat és érkárosodásokat okozhat [23]. Továbbá a hem képes a 
polimorfonukleáris leukocyták (PMN) aktivációjára és az endothelsejt által termelt adhéziós molekulák expressziójának fokozására is, ami a gyulladásos folyamatok felgyorsulását idézi elő [24]. Az oxidatív reakciók során a protoporfiringyưrű degradálódásával vas szabadul fel. A hemból felszabadult vas a membránok foszfolipid kettős rétegének hidrofób területein akkumulálódik és az ott zajló oxidációs folyamatok katalizátoraként viselkedik [25].

In vitro körülmények között az LDL oxidálására az átmeneti fémeken (például réz és vas), mieloperoxidáz és lipoxigenáz enzimeken, valamint a reaktívnitrogén-gyökökön kívül a hem is képes. A hem spontán beépül az LDL-molekulába és ezzel közvetlenül előidézi annak oxidatív módosulását [26]. A hem erősen kötődik a lipoproteinekhez, a plazmához adott hem körülbelül 80\%-a azonnal az LDL-hez és HDL-hez kötődik. Az oxidált LDL szerkezeti és biológiai tulajdonságai nagyban függenek az oxidáció mértékétől, toxicitása pedig a lipid-hidroperoxid-tartalomtól. A konjugált diének, lipid-hidroperoxidok és tiobarbitursav-reaktív anyagok (TBARS) az LDL-ben lévő alfa-tokoferol kimerülését eredményezik. Az LDL oxidációját felgyorsíthatja nyomnyi mennyiségü hidrogén-peroxid, leukocytaeredetű oxidánsok vagy lipid-hidroperoxidok. Az így képződött oxLDL az endothelsejteket kifejezetten károsítja, miáltal hozzájárulhat az atherosclerosis kezdeti szakaszában megjelenő fatty streak laesiók kialakulásához [27].

$\mathrm{Az}$ LDL oxidatív módosulását spektrofotometriásan nyomon követve a hem abszorbanciájának csökkenése és a képződő konjugált diének és lipid-hidroperoxid menynyiségének növekedése figyelhető meg [27]. Erre a kinetikára alapozva, az LDL oxidatív rezisztenciájának megítélése céljából klinikai laboratóriumi teszt alkalmazható. A teszt segítségével kimutatható az egyén véréből szeparált LDL-oxidációra való fogékonysága [28].

\section{Hemstressz elleni védekezés}

A hemtoxicitás első védelmi vonalát hemkötő plazmafehérjék alkotják. A haptoglobin egy akutfázis-plazmafehérje, amely képes megkötni a szabad hemoglobint, valamint elfedni a hemcsoportot. Amint a keringésben lévő haptoglobin kapacitása kimerül, a szabad hemet a plazmában nagy mennyiségben előforduló hemopexin köti meg. A hemopexin rendkívül nagy affinitással képes kötni a hemet, csökkentve ezzel az LDL-be való beépülését. A plazmában lévő hemoglobin, illetve szabad hem, a keringésben lévő haptoglobin és hemopexin fehérjék jelenléte ellenére is kompetitív módon sikeresen bekötődik az LDL-hez [29].

Az endothelsejtekben hem hatására egy intracelluláris védelmi mechanizmus aktiválódik, amit a hemoxigenáz-1 (HO-1) és ferritin rendszer képvisel [30] (1. ábra). A hemoxigenáz-1 egy hemdegradáló enzim, amely hasítja a porfiringyürüt, ezáltal biliverdin, szén-monoxid (CO) és szabad vas keletkezik. A ferritin egy olyan mul-

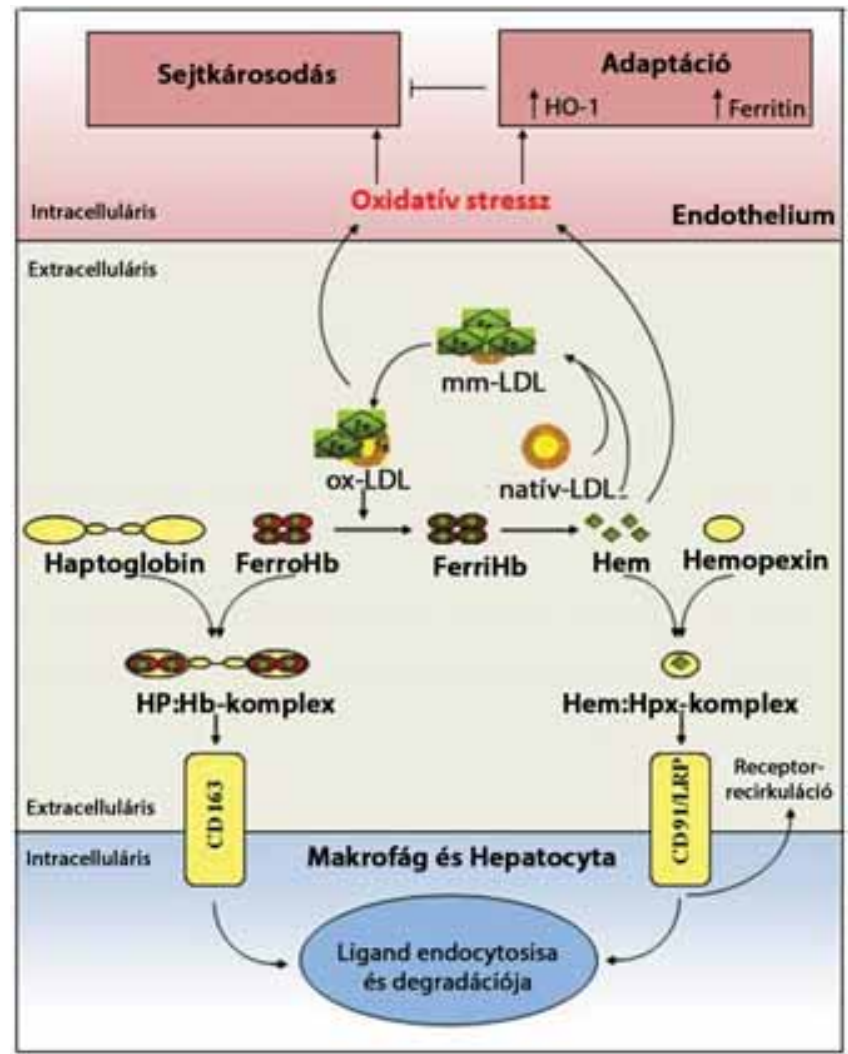

1. ábra

Extracelluláris hem, illetve hemoglobin eltávolítása. Az extracelluláris szabad hemoglobint a haptoglobin köti meg, majd a mak rofágokban a komplex a CDl63 receptoron keresztül kerül felvételre. A szabad hemmel a hemopexin képez komplexet, amely a hepatocytákban az LRP/CD91 receptoron keresztül internalizálódik. Mindkét receptor expressziója magas fagocitáló makrofágokban. A receptorkomplexek endocytosisa és degradációja után a hem a hem-oxigenáz enzim által degradálódik. A hem az LDL-hez is asszociálódhat, ezáltal előidézheti az LDL oxidatív modifikációját. Endothelsejtben az oxidált LDL hatására a védelmi mechanizmus részeként hemoxigenáz-l és ferritin indukálódik

timer fehérje, amely nagy mennyiségú vas tárolására képes. Az endothelsejtekben már az atherosclerosis korai szakaszában megfigyelhető hemoxigenáz-1 - és ferritinupreguláció. Ez az atheroscleroticus laesiókban található hem és hem-vas generálta lipidperoxidációs termékekre adott adaptív válasznak tekinthető $[30,31]$. Korábban vált ismertté, hogy az oxidált LDL legpotensebb hemoxigenáz-1 fehérjét indukáló komponense a lipid-hidroperoxid (13-hidroperoxioktadekadién-sav), amely a HO-1 promoterén lévő szabályozóelemhez kötődve transzkripciós szinten szabályoz [32].

A HO-1 - ferritin rendszer indukciója atherosclerosismodellben (LDL-receptor knock-out), egerekben, csökkentette az érrendszerben található plakkok mennyiségét, míg a HO-1-rendszer ón-protoporfirinnel való gátlása fokozott atherosclerosishoz vezetett [33]. A hemoxigenáz-1 enzim jelentőségét hangsúlyozza Yachie és mtsai esettanulmánya, amelyben egy hemoxigenáz1-defficiens gyermeket vizsgáltak. A gyermekben intravascularis hemolízist és az endothelsejtréteg súlyos sérü- 
lését diagnosztizálták [34]. Atherosclerosisra jellemző, zsíros lerakódásokat (fatty streak) és plakkokat (fibrous plaque) találtak az aortában, mesangioproliferatív glomerularis elváltozásokat a vesében [35]. Ezek hátterében intenzív hemoglobinoxidációt mutattak ki a gyermek plazmájában, ami a hemcsoport felszabadulásával az LDL nagymértékű oxidációját eredményezte [36].

$\mathrm{Az}$ endothelsejtek vas katalizálta oxidatív sérülését mérsékelni lehet exogén és endogén vaskelálókkal. A lazaroidok exogén kelálók, amelyek gátolják a lipidperoxidációs folyamatot, mérséklik a citotoxicitást [26]. Endogén vaskelálók között említhetjük a ferritint, amely ferroxidázaktivitása révén képes inaktiválni a hemből származó szabad vasat. Atherosclerosisban elhunyt betegek koszorúér-szöveti metszeteiben (miofibroblastokban, makrofágokban, endotheliumban) nagy mennyiségü immunoreaktív ferritin mutatható ki [37]. Belcher és mtsai kimutatták, hogy az alfa-tokoferol képes csökkenteni a hem oxidálta LDL endothelsejtekre gyakorolt citotoxikus hatását, valamint ex vivo kísérletekben gátolja az LDL hem, vagy réz mediálta oxidációját [38].

\section{Kutatási irányok}

Annak ellenére, hogy az elmúlt évtizedekben szerzett ismereteink nagymértékben gyarapodtak a vascularis kalcifikáció és vesebetegség összefüggéseiről, a mineralizáció kialakulásának pontos mechanizmusa még számos megválaszolatlan kérdést vet fel. Kétségtelenül óriási klinikai fontossággal bír a krónikus veseelégtelen betegek körében jelentkező érelmeszesedés kezelése és megelőzése. Ezt a célt szolgálja a kalcifikáció kialakulását elősegítő faktorok - például az oxidatív stressz - felderítése, valamint káros hatásuk semlegesítésére kidolgozott stratégiák alkalmazása.

Anyagi támogatás: A közlemény a TÁMOP-4.2.2, A-11/1/KONV-2012-0045, TÁMOP-4.2.6-15/12015-0001, OTKA-K 112333 (B. J.) és MTA-DE Vascularis Biológia, Thrombosis-Haemostasis Kutatócsoport (11003) támogatásával készült.

Szerzôi munkamegosztás: A szerzők egyenlő mértékben járultak hozzá a közlemény elkészültéhez. A cikk végleges változatát mindhárom szerző elolvasta és jóváhagyta.

Érdekeltségek: A szerzőknek nincsenek érdekeltségeik.

\section{Irodalom}

[1] Thompson, R. C., Allam, A. H., Lombardi, G. P., et al.: Atherosclerosis across 4000 years of human history: the Horus study of four ancient populations. Lancet, 2013, 381(9873), 1211-1222.

[2] Kuzela, D. C., Huffer, W. E., Conger, J. D., et al.: Soft tissue calcification in chronic dialysis patients. Am. J. Pathol., 1977, $86(2), 403-424$.
[3] Goodman, W. G., Goldin, J., Kuizon, B. D., et al.: Coronary-artery calcification in young adults with end-stage renal disease who are undergoing dialysis. N. Engl. J. Med., 2000, 342(20), 1478-1483.

[4] Braun, J., Oldendorf, M., Moshage, W., et al.: Electron beam computed tomography in the evaluation of cardiac calcifications in chronic dialysis patients. Am. J. Kidney Dis., 1996, 27(3), 394-401.

[5] Goldsmith, D. J., Covic, A., Sambrook, P. A., et al.: Vascular calcification in long-term haemodialysis patients in a single unit: a retrospective analysis. Nephron, 1997, 77(1), 37-43.

[6] Collins, A. J., Foley, R. N., Herzog, C., et al.: US Renal Data System 2012 Annual Data Report. Am. J. Kidney Dis., 2013, 61(1 Suppl 1.), A7, el-e476.

[7] Foley, R. N., Collins, A. J., Herzog, C. A., et al.: Serum phosphorus levels associate with coronary atherosclerosis in young adults. J. Am. Soc. Nephrol., 2009, 20(2), 397-404.

[8] Martín, M., Valls, J., Betriu, A., et al.: Association of serum phosphorus with subclinical atherosclerosis in chronic kidney disease. Sex makes a difference. Atherosclerosis, 2015, 241(1), 264-270.

[9] Kidney International: KDIGO clinical practice guideline for the diagnosis, evaluation, prevention, and treatment of chronic kidney disease-mineral and bone disorder. Kidney Int., 2009, 76(Suppl. 113), S1-S130.

[10] Shroff, R.: Phosphate is a vascular toxin. Pediatr. Nephrol., 2013, 28(4), 583-593.

[11] Neves, K. R., Graciolli, F. G., dos Reis, L. M., et al.: Vascular calcification: contribution of parathyroid hormone in renal failure. Kidney Int., 2007, 71(12), 1262-1270.

[12] Blokhina, O., Virolainen, E., Fagerstedt, K. V.: Antioxidants, oxidative damage and oxygen deprivation stress: a review. Ann. Bot., 2003, 91(2), 179-194.

[13] Locatelli, F., Canaud, B., Eckardt, K. U., et al.: Oxidative stress in end-stage renal disease: an emerging threat to patient outcome. Nephrol. Dial. Transplant., 2003, 18(7), 1272-1280.

[14] Cachofeiro, V., Goicochea, M., de Vinuesa, S. G., et al.: Oxidative stress and inflammation, a link between chronic kidney disease and cardiovascular disease. Kidney Int. Suppl., 2008, 74(111), S4-S9.

[15] Rossi, M., Campbell, K. L., Johnson, D. W., et al.: Protein-bound uremic toxins, inflammation and oxidative stress: a cross-sectional study in stage 3-4 chronic kidney disease. Arch. Med. Res., 2014, 45(4), 309-317.

[16] Mizobuchi, M., Towler, D., Slatopolsky, E.: Vascular calcification: the killer of patients with chronic kidney disease. J. Am. Soc. Nephrol., 2009, 20(7), 1453-1464.

[17] Sarnak, M. J., Levey, A. S., Schoolwerth, A. C., et al.: Kidney disease as a risk factor for development of cardiovascular disease: A statement from the American Heart Association Councils on kidney in cardiovascular disease, high blood pressure research, clinical cardiology, and epidemiology and prevention. Circulation, $2003,108(17), 2154-2169$.

[18] Castilla, P., Dávalos, A., Teruel, J. L., et al.: Comparative effects of dietary supplementation with red grape juice and vitamin $\mathrm{E}$ on production of superoxide by circulating neutrophil NADPH oxidase in hemodialysis patients. Am. J. Clin. Nutr., 2008, 87(4), 1053-1061.

[19] Ziouzenkova, O., Asatryan, L., Akmal, M., et al.: Oxidative crosslinking of ApoB100 and hemoglobin results in low density lipoprotein modification in blood. Relevance to atherogenesis caused by hemodialysis. J. Biol. Chem., 1999, 274(27), 18916-18924.

[20] Diepeveen, S. H., Wetzels, J. F., Bilo, H. J., et al.: Cholesterol in end-stage renal disease : the good, the bad or the ugly ? Neth. J. Med., 2008, 66(2), 53-61.

[21] Shaikh, M., Martini, S., Quiney, J. R., et al.: Modified plasmaderived lipoproteins in human atherosclerotic plaques. Atherosclerosis, 1988, 69(2-3), 165-172. 
[22] Libby, P.: The vascular biology of atherosclerosis: overview and state of the art. Am. J. Cardiol., 2003, 91(3A), 3A-6A.

[23] Balla, J., Jacob, H. S., Balla, G., et al.: Endothelial-cell heme uptake from heme proteins: induction of sensitization and desensitization to oxidant damage. Proc. Natl. Acad. Sci. U.S.A., 1993, 90(20), 9285-9289.

[24] Graça-Souza, A. V., Arruda, M. A., de Freitas, M. S., et al.: Neutrophil activation by heme: Implications for inflammatory processes. Blood, 2002, 99(11), 4160-4165.

[25] Balla, G., Vercellotti, G. M., Muller-Eberbard, U., et al.: Exposure of endothelial cells to free heme potentiates damage mediated by granulocytes and toxic oxygen species. Lab. Invest., 1991, 64(5), 648-655.

[26] Balla, G., Vercellotti, G. M., Eaton, J. W., et al.: Iron loading of endothelial cells augments oxidant damage. J. Lab. Clin. Med., 1990, 116(4), 546-554.

[27] Balla, G., Jacob, H. S., Eaton, J. W., et al.: Hemin: a possible physiological mediator of low density lipoprotein oxidation and endothelial injury. Arterioscler. Thromb. Vasc. Biol., 1991, 11(6), 1700-1711

[28] Miller, Y. I., Shaklai, N.: Kinetics of hemin distribution in plasma reveals its role in lipoprotein oxidation. Biochim. Biophys. Acta, 1999, 1454(2), 153-164.

[29] Ujhelyi, L., Balla, J., Muszbek, L., et al.: A microassay to assess the oxidative resistance of low-density lipoproteins. Clin. Chem., 1998, 44(8), 1762-1764.

[30] Balla, G., Jacob, H. S., Balla, J., et al.: Ferritin: a cytoprotective antioxidant strategem of endothelium. J. Biol. Chem., 1992, 267(25), 18148-18153.
[31] Agarwal, A., Balla, J., Balla, G., et al.: Renal tubular epithelial cells mimic endothelial cells upon exposure to oxidized LDL. Am. J. Physiol., 1996, 271(4), F814-F823.

[32] Hill-Kapturczak, N., Voakes, C., Garcia, J., et al.: A cis-acting region regulates oxidized lipid-mediated induction of the human heme oxygenase-1 gene in endothelial cells. Arterioscler. Thromb. Vasc. Biol., 2003, 23(8), 1416-1422.

[33] Ishikawa, K., Sugawara, D., Wang, Xp., et al.: Heme oxygenase-1 inhibits atherosclerotic lesion formation in LDL-receptor knockout mice. Circ. Res., 2001, 88(5), 506-512.

[34] Yachie, A., Niida, Y., Wada, T., et al.: Oxidative stress causes enhanced endothelial cell injury in human heme oxygenase-1 deficiency. J. Clin. Invest., 1999, 103(1), 129-135.

[35] Kawashima, A., Oda, Y., Yachie, A., et al.: Heme oxygenase-1 deficiency: the first autopsy case. Hum. Pathol., 2002, 33(1), 125-130.

[36] Jeney, V., Balla, J., Yachie, A., et al.: Pro-oxidant and cytotoxic effects of circulating heme. Blood, 2002, 100(3), 879-887.

[37] Juckett, M. B., Balla, J., Balla, G., et al.: Ferritin protects endothelial cells from oxidized low density lipoprotein in vitro. Am. J. Pathol., 1995, 147(3), 782-789.

[38] Belcher, J. D., Balla, J., Balla, G., et al.: Vitamin E, LDL, and endothelium. Brief oral vitamin supplementation prevents oxidized LDL-mediated vascular injury in vitro. Atheroscler. Thromb., 1993, 13(12), 1779-1789.

(Balla József dr., Debrecen, Nagyerdei krt. 98., 4032 e-mail: balla@belklinika.com)

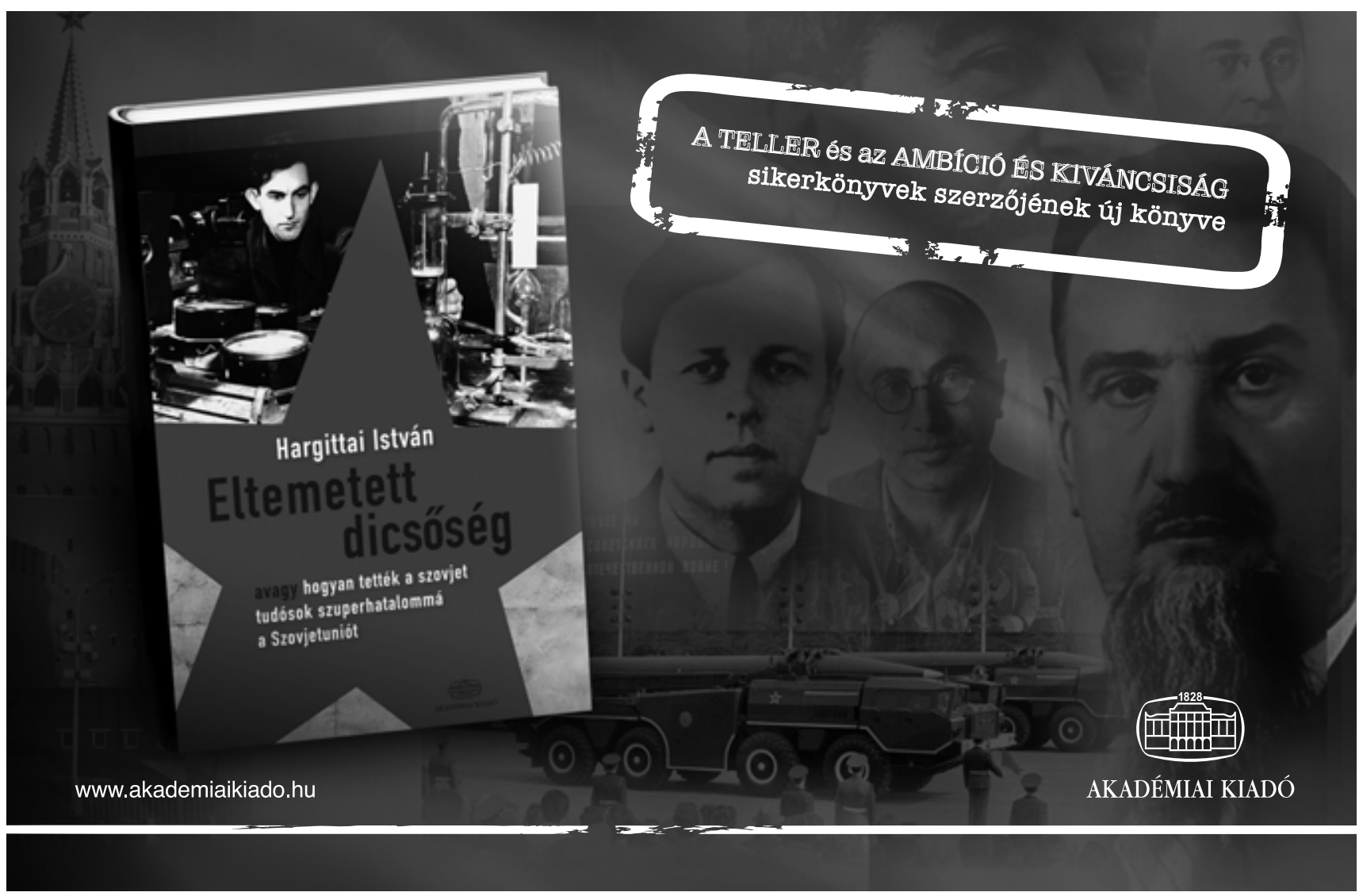

